Similar tests were made with glutathione. This substance proved much less active than ascorbic acid. A dilution of $1: 20,000$ failed to inactivate virus in 24 hours, while a dilution of $1: 200$ inactivated 10 doses completely and 100 infective doses partially.

It appears, therefore, that ascorbic acid has the same effect on vaccine virus as on the virus of poliomyelitis and on diphtheria toxin. Preliminary experiments indicate a similar effect on coli phage. It may well be, therefore, that the phenomenon is a general one and is related to a common or related group in the chemical composition of viruses and diphtheria toxin, effected by oxido-reducing substances, of which ascorbic acid is the most active.

Further investigations are in progress.

I. J. KLIGLER.

H. BERNKOPF

(Oscar S. Hornick Research Fellow).

Department of Hygiene and Bacteriology,

Hebrew University, Jerusalem.

April 23

${ }^{1}$ Jungeblut, ( . W., J. Exp. Med., 62, 517 (1935) ; Jungeblut, C. W., and Zwemmer, R. I., Proc. Soc. Exp. Med. and Biol., 32, 1229 (1935),

' Kligler, I. J., NAture, 138, 291 (1936).

\section{Correlation Phenomena and Hormones in Selaginella}

IT has been known for a long time that the anglemeristems present at every branching of Selaginella shoots, which normally give rise to rhizophores, may be induced to develop as leafy shoots instead of rhizophores ${ }^{1}$. This altered development occurs when pieces of shoot including a branching but with the shoot apices removed are used as cuttings. This is illustrated for $S$. Martensii in Fig. $1 a$, which depicts a specimen from an experiment in which fourteen pieces of shoot were used. Thirteen of these showed the development of leafy shoots from the anglemeristems while the remaining one showed no further development.
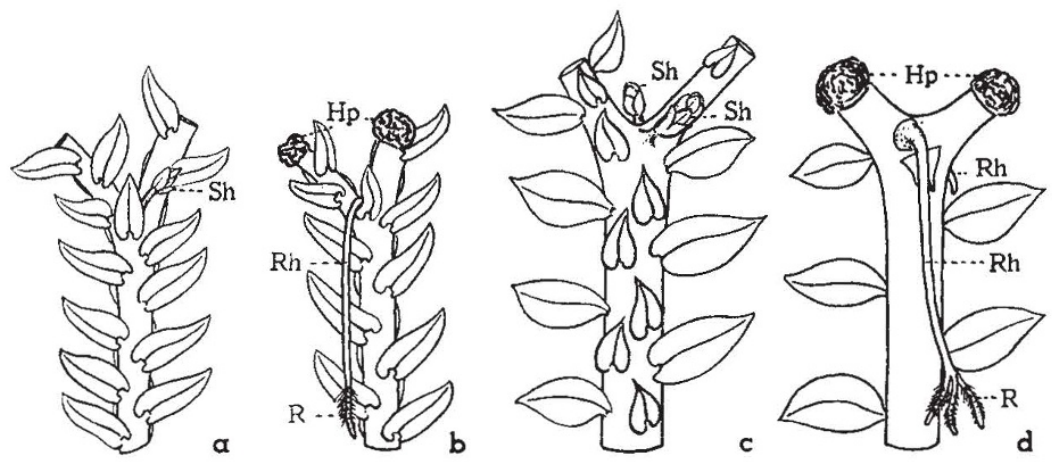

Fig. 1.

Selaginella Martensii. (a) UNTREATED LENGTH OF SHOOT; (b) LENGTH OF SHOOT WITH HETEROAUXIN PASTE; $(c)$ AND $(d)$ COMPARABLE LENGTHS OF SHOOT OF S. Lobbii. Sh, SHOOT; Rh, RHIZOPHORE; $R$, ROOT; $H p$, HETEROAUXIN PASTE. $\left(\times 1 \frac{1}{2}\right)$.

The presence of a correlating influence diffusing backwards from the shoot apices has been inferred from the known facts, and it seemed worth while to investigate whether hormones such as heteroauxin (3-indole acetic acid) were concerned. Pieces of shoot were prepared as above, and the cut upper surfaces were then smeared with heteroauxin paste (prepared by the method described by Laibach ${ }^{2}$ ). Twelve pieces of shoot were used, and all showed the development of a rhizophore from the angle-meristem (see Fig. 1 b). Comparable results have been obtained with the more strongly growing $S$. Lobbii, which frequently shows two angle-meristems in an active condition at each branching. In an experiment with eleven pieces of shoot treated with heteroauxin paste, seven specimens showed the development of a single rhizophore, the other meristem remaining dormant; two showed the development of two rhizophores (see Fig. $1 d$ ); one the development of a rhizophore followed by the development of a shoot from the other meristem; the remaining specimen showed no further development. Similar shoot pieces without heteroauxin paste showed the development of one or two leafy shoots (see Fig. 1 c); no rhizophores were formed.

These preliminary experiments indicate that the presence or absence of heteroauxin is an effective factor in determining whether an angle-meristem shall develop as a rhizophore, leafless and positively geotropic, or as a plagiotropic leafy shoot. They do not prove that the correlating influence normally exercised by the shoot apex is in the nature of a hormone mechanism, but they lend support to this view.

A more extensive series of experiments relating to correlation phenomena in Selaginella is in progress.
Botany Department,
S. WILLTAMS.

University,

Glasgow.

April 19.

1 Williams, S., "An Analysis of the Vegetative Organs of Seluginell" grandis", Trans. Roy. Soc. Edin., 57 (19:31).

${ }^{2}$ Laibach, F., "Uber die Auslösung von Kallus- und Wurzelbildung durch $\ddot{\beta}$-Indolylessigsäure", Ber. Bot. Ges?ll., 53 (1935).

\section{A Device for the Observation of Root Growth in the Soil}

STudies of root systems have in the past been accomplished by various methods of excavation in situ or by the growing of plants in specially constructed boxes which can be dismantled to allow removal of the soil. It is impossible to conduct developmental studies by this means unless a number of subjects are examined at various stages of their growth, and in any event the process is extremely laborious. In work on fruit trees at East Malling, Rogers ${ }^{1}$ has designed observation trenches which are in the form of a walled chamber fitted with plate-glass windows. This givesa view of rootlets impinging against the glass.

The necessity for this type of study upon arable crops and grasses has led me to devise a cheap and convenient means suited to field conditions. Land under rotation on a commercially run farm must undergo cultural operations in winter which make it imperative to move the units after the crop is harvested. Cheapness renders it possible to install a sufficient number of points of observation to satisfy statistical needs. A less permanent and expensive method is therefore desirable than in the case of an experimental orchard.

Glass tubes, closed at the lower end, are let into the soil down holes bored to a slightly larger diameter. 